\title{
Reducing External Chilling Injury in Stored 'Hass' Avocados with Dry Heat Treatments
}

\author{
Allan B. Woolf, Christopher B. Watkins', Judith H. Bowen, Michael Lay-Yee, \\ John H. Maindonald, and Ian B. Ferguson \\ The Horticulture and Food Research Institute of New Zealand, Mt. Albert Research Centre, Private Bag \\ 92169, Auckland, New Zealand
}

\begin{abstract}
Additional index words. ethylene, heat shock proteins, gene expression, fruit ripening, Persea americana, disinfestation, postharvest physiology
\end{abstract}

\begin{abstract}
Hass' avocados (Persea americana Mill.) were heated in air at 25 to $46 \mathrm{C}$ for 0.5 to 24 hours and stored at 0 , 2 , or 6C. After storage, fruit were ripened at $20 \mathrm{C}$ and their quality was evaluated. In unheated fruit, external chilling injury occurred in fruit stored at $\mathrm{O}$ or $2 \mathrm{C}$, hut not $6 \mathrm{C}$. Chilling injury was also evident after storage at $2 \mathrm{C}$ in fruit heated at $34 \mathrm{C}$, and to a lesser extent in fruit heated at 36C. A heat treatment (HT) of 38C for 3, 6, or 10 hours and $40 \mathrm{C}$ for 0.5 hour further reduced external chilling injury induced by storage at $2 \mathrm{C}$. These HTs did not reduce internal fruit quality and resulted in more marketable fruit than unheated fruit stored at 6C. Low-temperature storage and HT slowed avocado ripening, resulting in longer shelf life after storage. In flesh tissue sampled directly after selected HTs, the levels of mRNA homologous to cDNA probes for two plant heat-shock protein (HSP) genes (HSP17 and HSP70) increased to a maximum at $40 \mathrm{C}$ and declined at higher temperatures. These increases in gene expression coincided with the extent to which HTs prevented chilling injury. Hot-air HTs confer significant protection against low-temperature damage to avocados.
\end{abstract}

Long-distance transport and marketing of avocados is limited by the fruit's relatively short storage and shelf life. Although lowtemperature storage reduces ripening rate and may be a means of disinfestation (Kerbel et al., 1987; Sanxter et al., 1994), avocados are susceptible to chilling injury below 6C. The symptoms are primarily a blackening of the skin's surface. Internal injury is lessclearly defined. Flesh symptoms such as browning or graying of the mesocarp have been described (Zauberman et al., 1985), although these symptoms may not be solely a low-temperature response (Bower and Cutting, 1988).

Heat treatments (HTs) are receiving increasing attention as a means of reducing chilling injury in some fruit. Hot air or hot water HTs reduce chilling injury in mango (McCollum et al., 1993), tomato (Lurie and Klein, 1991), and orange (Wild and Hood, 1989). HTs can also be used as a disinfestation technique and to address storage problems (Paull, 1990). Sanxter et al. (1994) have reported beneficial effects of air HTs on quality of 'Sharwil' avocados stored at $<6 \mathrm{C}$, and preliminary work with 'Hass' suggests similar results (Florissen et al., 1994; Woolf et al., 1994).

Reported effects of HTs on the physiology of various fruit include reduced ethylene production (Klein and Lurie, 1991; Paull, 1990), reduced gene expression of ACC oxidase (Picton and Grierson, 1988), lower levels of ion leakage (Saltveit, 1991), and slower rates of flesh softening and pectin solubilization (Klein et al., 1990). The effect of HTs in reducing chilling injury may be related to some of the above responses. However, chilling injury is manifested in a variety of ways in different fruit, such as skin blackening in avocado (Sanxter et al., 1994), flesh gelling in persimmon (MacRae, 1987), and inhibition of ripening in apple

Received for publication 17 Jan. 1995. Accepted for publication 22 June 1995. This work was funded by the Agriculture and Marketing Research and Development Trust, project no. 1171/1178. We gratefully acknowledge the assistance of K. Spooner and thank L. Nover (Halle, Germany) for the gifts of the $h s p$ cDNA clones. Special thanks to A. Gunson and S. Bamett for assistance with statistical analyses and graphs. The cost of publishing this paper was defrayed in part by the payment of page charges. Under postal regulations, this paper therefore must be hereby marked advertisement solely to indicate this fact.

'Present address: Dept. of Fruit and Vegetable Science, Cornell Univ., Ithaca, NY 14853 .
(Klein and Lurie, 1990) and tomato (Lurie and Klein, 1991). Thus, the range of chilling symptoms suggests an array of effects from HTs.

Responses of plant tissues to high temperatures often include reduced protein synthesis, with induction of specific heat-shock protein (HSP) genes. It has been proposed that HSPs confer thermotolerance by protecting other proteins from breakdown through a chaperone-like function or by removing heat-denatured proteins in the cell (Howarth and Ougham, 1993). HSPs have been found in heated papaya (Paull, 1990), apples (Lurie and Klein, 1990), and tomatoes (Lurie and Klein, 1991), and HSP gene expression is enhanced in heated tomatoes (Lurie et al., 1993). Many beneficial effects of HTs occur at temperatures where HSP gene expression is high (e.g., >36C), and HSPs have been implicated in reduced chilling injury after HT (Lafuente et al., 1991).

We investigated the response of 'Hass' avocados to dry air HTs [nonsaturating relative humidities (RHs)], particularly with respect to reducing chilling injury during subsequent low-temperature storage. We used a range of durations at each of several temperatures to define an optimal HT to reduce chilling injury. Using response surface analysis, resulting in contour plots, has helped define optimal treatments. We also examined HSP gene expression in relation to HTs and the subsequent development of chilling injury in storage.

\section{Materials and Methods}

Fruit handling. Export-quality 'Hass' avocados were obtained from a commercial packhouse in the Bay of Plenty, New Zealand. Fruit were graded for uniformity of size $(205 \pm 15 \mathrm{~g})$ and freedom from blemishes and placed in a $20 \mathrm{C}$ room ( $\mathrm{RH} 65 \% \pm 10 \%$ ) overnight before HT.

Experiments. Three experiments were carried out involving HTs of a range of temperatures and durations. In Expt. 1, fruit were treated at $25,34,38$, or $42 \mathrm{C}$ for 6 or $24 \mathrm{~h}$ and stored at either 0 or $6 \mathrm{C}$ for 3 weeks. In Expt. 2, fruit were treated at 34, 36, 38, 40, or $42 \mathrm{C}$ for $3,6,10$, or $24 \mathrm{~h}$. In Expt. 3, fruit were treated at 40, 42, 44, or $46 \mathrm{C}$ for $0.5,1.5,3$, or 6 h. In Expts. 2 and 3 fruit were stored at $2 \mathrm{C}$ for 4.5 weeks and these experiments were undertaken twice. 
HT system. HTs were carried out simultaneously in six identical 147-liter chambers using a computer-controlled 340-W heater and fan, which circulated air at a rate of $10 \mathrm{~m} \cdot \mathrm{s}^{-1}$ through a single layer of fruit on a $45 \times 70-\mathrm{cm}$ plastic mesh grid. Air and internal fruit temperatures were measured and logged every 2-min using Squirrel data loggers (model 1206; Grant, Cambridge). To measure the internal temperature, a thermistor temperature probe (CM-UUV5-1; Grant) was inserted at the stem end to the seed surface of one fruit per chamber. Timing of the HT duration was initiated when the internal temperature had reached the target temperature $(2 \pm$ $0.25 \mathrm{~h}$ from the commencement of heating). After reaching the target temperature, fruit within a given chamber varied by $\pm 0.25 \mathrm{C}$ over time and $\pm 0.5 \mathrm{C}$ spatially. $\mathrm{RH}$ was not controlled, but three 0.5 -liter containers of water were placed in each chamber. $\mathrm{RH}$ dropped to $40 \% \pm 5 \%$ during the initial 2-h heating period and stabilized at $60 \% \pm 10 \%$ for the rest of the HT.

HT of fruit and measurements. Forty-eight fruit were weighed and placed in each chamber at a given temperature. For each treatment duration, 12 fruit were removed randomly during the HT period. After removal from HT, weight loss was determined on individual fruit. All heated fruit were placed in conditions that induced chilling injury (Expt. 1, 0C; Expts. 2 and 3, 2C) and additional unheated (20C) control fruit were held at $6 \mathrm{C}$, the New Zealand industry standard for avocado storage. In Expt. 1, heated fruit was also stored at $6 \mathrm{C}$. A replicate of 12 unheated fruit were held at 20C directly after harvest and internal fruit quality was examined when fruit were ripe (see below).

Fruit quality. Immediately after removal from storage, external injury (blackening, pitting of the skin surface) due to chilling injury or heat damage was rated on a relative scale $(0$ to 3 in 0.5 intervals; $0=$ no occurrence, $3=$ blackening of $>90 \%$ of the fruit surface). Fruit quality after ripening at $20 \mathrm{C}$ was evaluated as each fruit reached a ripe-to-eat or optimum-eating-ripeness stage of maturity, which was determined by gently squeezing fruit daily, and the number of days to reach ripeness was recorded (shelf life). Several fruit quality factors were rated, including uneven ripening (uneven flesh softening such that flesh tissue adhered to the seed when the fruit was cut in half), internal rots (stem-end and body rots), tissue breakdown (presence of green fruit tissue adhering to the skin when peeled away from the flesh), vascular browning (browning of the vascular strands running vertically through the fruit tissue), and flesh browning (browning of the fruit tissue not due to disease or vascular browning). Each factor was rated on a scale of 0 to 3 in intervals of 1 (Hopkirk et al., 1994), where $0=$ no occurrence; 1 = slight; 2 = a level at which the consumer would notice and possibly reject the fruit; $3=$ extreme. Informal taste tests were also carried out on selected HTs and compared with unheated fruit stored at $6 \mathrm{C}$.

Ethylene production and respiration rate. Ethylene production and respiration rates were measured daily on fruit from selected treatments held at 20C after removal from storage. Five fruit per treatment were sealed individually in 1-liter containers and, after $1 \mathrm{~h}, 1-\mathrm{ml}$ gas samples were removed by syringe and ethylene and carbon dioxide concentrations were measured by gas chromatography using flame-ionization and thermal-conductivity detectors, respectively (Philips PU4500; Pye Unicam, Cambridge).

RNA extraction and Northern analysis. Fruit of selected treatments were sampled immediately after HTs in Expt. 2. A series of samples was also taken from fruit that had been heat-treated at $38 \mathrm{C}$ for $6 \mathrm{~h}$ and subsequently held in storage (2C) for 6 weeks. Fruit flesh to a depth of $10 \mathrm{~mm}$ was removed with a 10 -mm (ID) cork borer from the equator of the fruit, and l-g samples (with the skin removed) were immediately frozen in liquid nitrogen and held at
-80C. Total RNA was extracted, denatured, fractionated $(30 \mu \mathrm{g} /$ lane) and transferred to a Hybond-N+ (Amersham) membrane as described by Veierskov et al. (1992). The inserts from pMON9575 (petunia HSP70 cDNA; Winter et al., 1988) and pFS1968 (soybean HSP17 cDNA; Schoffl et al., 1984) were labelled with ${ }^{32} \mathrm{P}$ using a random primers DNA labelling system (BRL). Hybridization was carried out according to the Amersham Hybond-N+ protocol. After hybridization, the membrane was washed twice for $10 \mathrm{~min}$ in $2 \times \mathrm{SSC}$ and $0.1 \%$ SDS at room temperature, then once in $1 \times \mathrm{SSC}$ and $0.1 \% \mathrm{SDS}$ at $65 \mathrm{C}$ for $15 \mathrm{~min}$. The membrane was exposed to Kodak XAR film with intensifying screens at $-80 \mathrm{C}$.

Statistical analyses. Experiment 1 was an unreplicated experiment, so SES are based on variation between fruit and may underestimate the true SE.

SE of the mean (Fig.

SE

To present' the large quantities of data obtained from the

contour plots. These show the effect of temperature and duration

(Maindonald, 1992) using the local regression methods imple-

Statistical Sciences, 1991). This algorithm uses planes or quadratic surfaces to represent the response in the locality of each fitted

that are close to the current point are assigned the highest weight,

increases. The loess function repeats until there is a single smooth

deviation from the variability of data about the fitted surface,

tions result in contour lines (bold, solid lines with large numbers

either side of the contour lines (broken lines with small nonbold

transformation. In Figs. 2-5, the results of Expts. 2 and 3 were

numbers) represents the mean value for the two replicates. In Figs. 2 and 3, data are presented as the average severity of the factor

and severe levels $(>1)$ of that factor referred to as the incidence (B). For example, the $50 \%$ contour line of Fig. $2 \mathrm{~B}$ shows HTs that result

95\% confidence interval lines appear on either side of the contour

which no quality factor examined was $>1$, thus representing fruit acceptable to the consumer. Numerical values presented in the text are mean $\pm 95 \%$ confidence intervals.

Because maximum respiration rates, time to initiation of the ethylene climacteric $\left(>1 \mu \mathrm{l} \cdot \mathrm{kg}^{-1} \cdot \mathrm{h}^{-1}\right)$, maximum ethylene production, and the days to maximum level of ethylene production were measured on selected treatments, there were insufficient data points to use the S-Plus loess function. Data were analyzed by a two-way analysis of variance (Lawes Agricultural Trust, 1990; Genstat Statistical Package). The data for maximum level of ethylene production and respiration rate were log-transformed before analysis because their distribution was skewed.

\section{Results}

External appearance after storage. External injury was manifest as blackening of the skin and was caused by low temperature (i.e., chilling injury) and HTs (i.e., heat injury). Although heat injury occurred predominantly at the stem end of the fruit, and 
chilling injury was not localized, we could not visually differentiate between heat and chilling injury of the skin after storage. Thus, in presenting these results, no differentiation is made between heat and chilling injury. Such a differentiation is described, however, in the discussion.

External injury was observed in unheated fruit (20C) stored at $0 \mathrm{C}$ for 3 weeks (severity rating of $1.8 \pm 0.3$ ) and $2 \mathrm{C}$ for 4.5 weeks $(0.8 \pm 0.3)$ (Fig. 2). In contrast, unheated fruit stored at $6 \mathrm{C}$ had minimal damage $(0.2 \pm 0.2$ and $0.1 \pm 0.2$ for Expts. 1 and 2-3, respectively).

External damage of fruit stored at $0 \mathrm{C}$ was markedly reduced by HTs of 38C for either 6 or $24 \mathrm{~h}$ (Expt. 1, Fig. 1). The minimal damage $(0.2 \pm 0.2)$ that did result from a $38 \mathrm{C}$ HT for $6 \mathrm{~h}$ was identical to that in unheated fruit stored at 6C (Fig. 1). Minimal damage was found in fruit stored at $6 \mathrm{C}$ after HTs of 25 or $34 \mathrm{C}$, and there was a slight increase in damage after the 38C HT, particularly for the 24-h duration. For fruit stored at 0C, HTs of 6 and $24 \mathrm{~h}$ at $34 \mathrm{C}$ slightly reduced damage compared to $25 \mathrm{C}$ HTs, but not compared with unheated $20 \mathrm{C}$ controls. HTs of $42 \mathrm{C}$ resulted in significant damage, which was evident even before storage in the 24-h treatment (data not shown). After storage at either 0 or $6 \mathrm{C}$, fruit had extensive external damage, which increased with greater HT duration (Fig. 1).

In Expts. 2 and 3, a wider range of temperatures and durations was investigated. The contour plot (Fig. 2) shows that, for fruit stored at $2 \mathrm{C}$, minimal external damage levels were obtained with HTs of $38 \mathrm{C}$ for 3,6 , and $10 \mathrm{~h}$ and $40 \mathrm{C}$ for $0.5 \mathrm{~h}$. This was so with severity (Fig. 2A; <0.5) and percent incidence (Fig. 2B; 0\%). These levels of damage were not significantly different from those of unheated fruit (20C) stored at 6C, but were lower than those in unheated fruit stored at $2 \mathrm{C}$. Two areas of Fig. 2 revealed HTs that resulted in damage levels higher than those from 38C. Temperatures of 34 and $36 \mathrm{C}$ resulted in a damage severity of about 1 and a percent incidence of about $25 \%$, which were similar to those of unheated fruit stored at $2 \mathrm{C}$. HTs of $42 \mathrm{C}$ for $3 \mathrm{~h}$ and higher temperatures resulted in extensive external damage (damage rating contour lines $>1$, Fig. 2A). At all temperatures, damage was

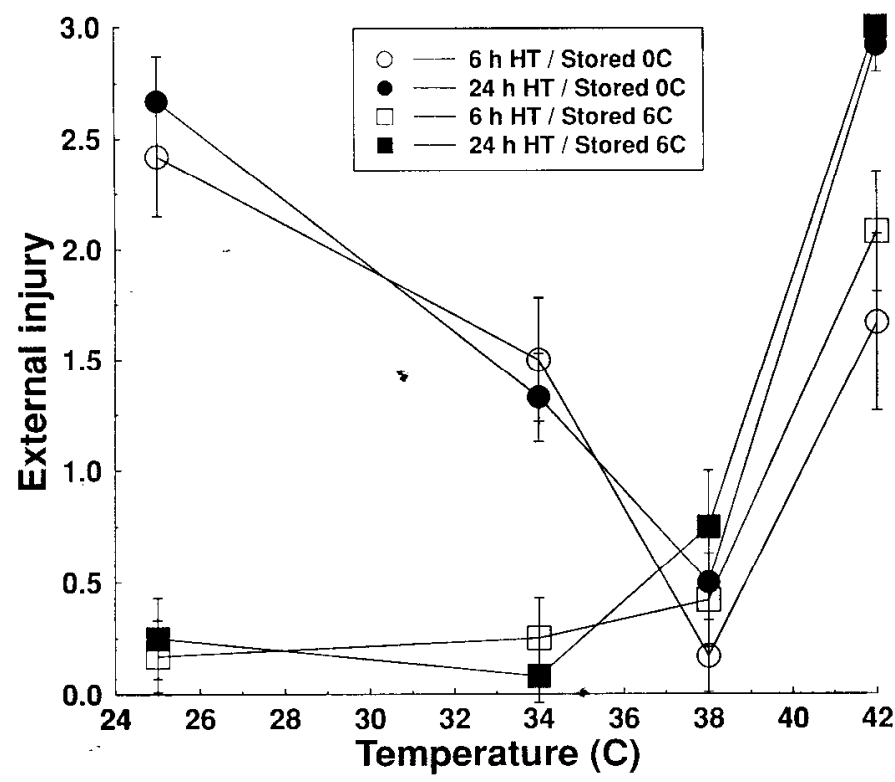

Fig. 1. Mean severity of external injury of avocado after heat treatment at 25, 34 38 , or $42 \mathrm{C}$ for 6 or $24 \mathrm{~h}$ followed by storageat 0 or $6 \mathrm{C}$ for 3 weeks. Unheated 20C) fruit stored at 0 and $6 \mathrm{C}$ had external injury level a of $1.8 \pm 0.3$ and $0.2 \pm 0.2$ respectively. External injury rated on a scale of 0 to $3(0=$ none. $3=$ extreme $)$. Vertical bars indicate SE of the mean. greater with longer durations.

Internal fruit quality. Uneven ripening or softening of the fruit flesh (an important indicator of fruit quality) occurred in unheated fruit stored at $2 \mathrm{C}$ (severity of $0.4 \pm 1.0$; incidence of $10 \% \pm 25 \%$ ). The severity ratings were $<1$ in treatments of $40 \mathrm{C}$ for $6 \mathrm{~h}$ and less and lower temperatures ( 34 to $38 \mathrm{C}$ ) at durations of $10 \mathrm{~h}$ and less (Fig. 3). A treatment duration of $24 \mathrm{~h}$ increased uneven ripening at nearly all temperatures. The incidence of uneven ripening was minimal $(<10 \%)$ in HTs of $40 \mathrm{C}$ for 0.5 and $1.5 \mathrm{~h}, 38 \mathrm{C}$ for 3 to 10 $\mathrm{h}$, and for $3 \mathrm{~h}$ at $34 \mathrm{C}$ and $36 \mathrm{C}$.

Reduced fruit quality was also due to internal rots, tissue breakdown, vascular browning, and flesh browning and showed a pattern of response to HTs similar to that of uneven ripening (data not shown). To assess quality of ripe fruit, the proportion of sound fruit, i.e.,, the proportion of fruit with no moderate or severe injury, was determined (Fig. 4). HTs that resulted in more sound fruit than unheated fruit stored at $6 \mathrm{C}(31 \%)$ were $36 \mathrm{C}$ for 3 and $6 \mathrm{~h}, 38 \mathrm{C}$ for 3,6 , and $10 \mathrm{~h}$ and $40 \mathrm{C}$ for $0.5 \mathrm{~h}$. HTs $>42 \mathrm{C}$ were associated with lower fruit quality, thus resulting in almost no acceptable fruit. HTs

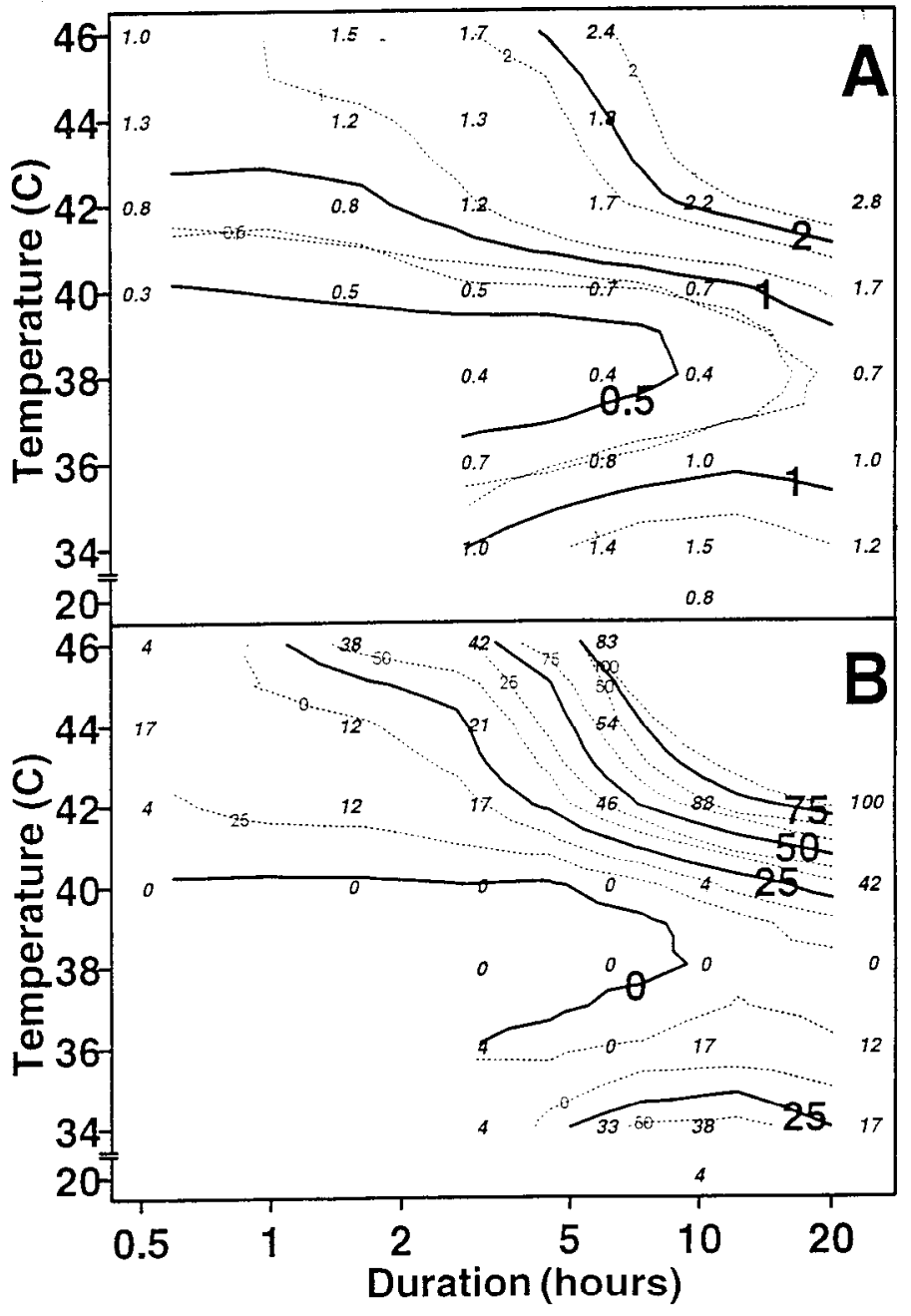

Fig. 2. Contour plot of mean severity (A) and percentage incidence (B) (percentage of fruit with levels $>1$ ) of external injury of avocado after heat treatment at 34 to $46 \mathrm{C}$ for 0.5 to $24 \mathrm{~h}$ followed by storage at $2 \mathrm{C}$ for 4.5 weeks. Severity of external injury of unheated (20C) fruit stored at either $2 \mathrm{C}$ or $6 \mathrm{C}$ was $0.8 \pm 0.3$ and $\mathrm{O} . / \mathrm{f}$ 0.2 , respectively, and incidence was $4 \% \pm 8 \%$ and $0 \% \pm 0 \%$, respectively. External injury rated on a scale of 0 to $3(0=$ none, $3=$ extreme). Bold lines (with large numbers) represent fitted contour lines, and broken lines on either side (small nonbold numbers) represent 95\% confidence intervals. Small, bold italicized numbersrepresent the mean values for each treatment combination. See Materials and Methods for statistical analysis details. 
of 34 and $36 \mathrm{C}$ for longer durations also reduced internal fruit quality. No differences in taste or off-flavors were noted between optimum HTs and unheated controls stored at 6C.

Shelf life. Heat-treated fruit had a longer shelf life (time for fruit to ripen at $20 \mathrm{C}$ as assessed by time to soften) than unheated fruit (Fig. 5). Unheated fruit stored at 2 or $6 \mathrm{C}$ had a shelf life of $8.2 \pm 1.4$ and $6.3 \pm 2.6$ days, respectively. The contour plot shows that HTs could extend shelf life to as much as $10.2 \pm 1.4$ days ( $40 \mathrm{C}$ for 0.5 h; Fig. 5) without reducing fruit quality (Fig. 4). Shelf life of untreated fruit ripened directly without cool storage was $11.2 \pm 1.4$ days. Thus, HTs retained much of the shelf life lost during cool storage.

Ethylene production and respiration rate. The onset of the ethylene climacteric (beyond a threshold value of $1 \mu \mathrm{l} \cdot \mathrm{kg}^{-1} \cdot \mathrm{h}^{-1}$ ) for fruit after storage was not affected by temperatures of 20 to $42 \mathrm{C}$. However, at 44 and $46 \mathrm{C}$, the climacteric rise was delayed by about 3 days for the 6-h treatment (Table 1). The number of days to maximum ethylene production was also affected by temperature, but not by increasing the duration of HT from 0.5 to $6 \mathrm{~h}$ (data not shown). The effect of HT on maximum ethylene production rates

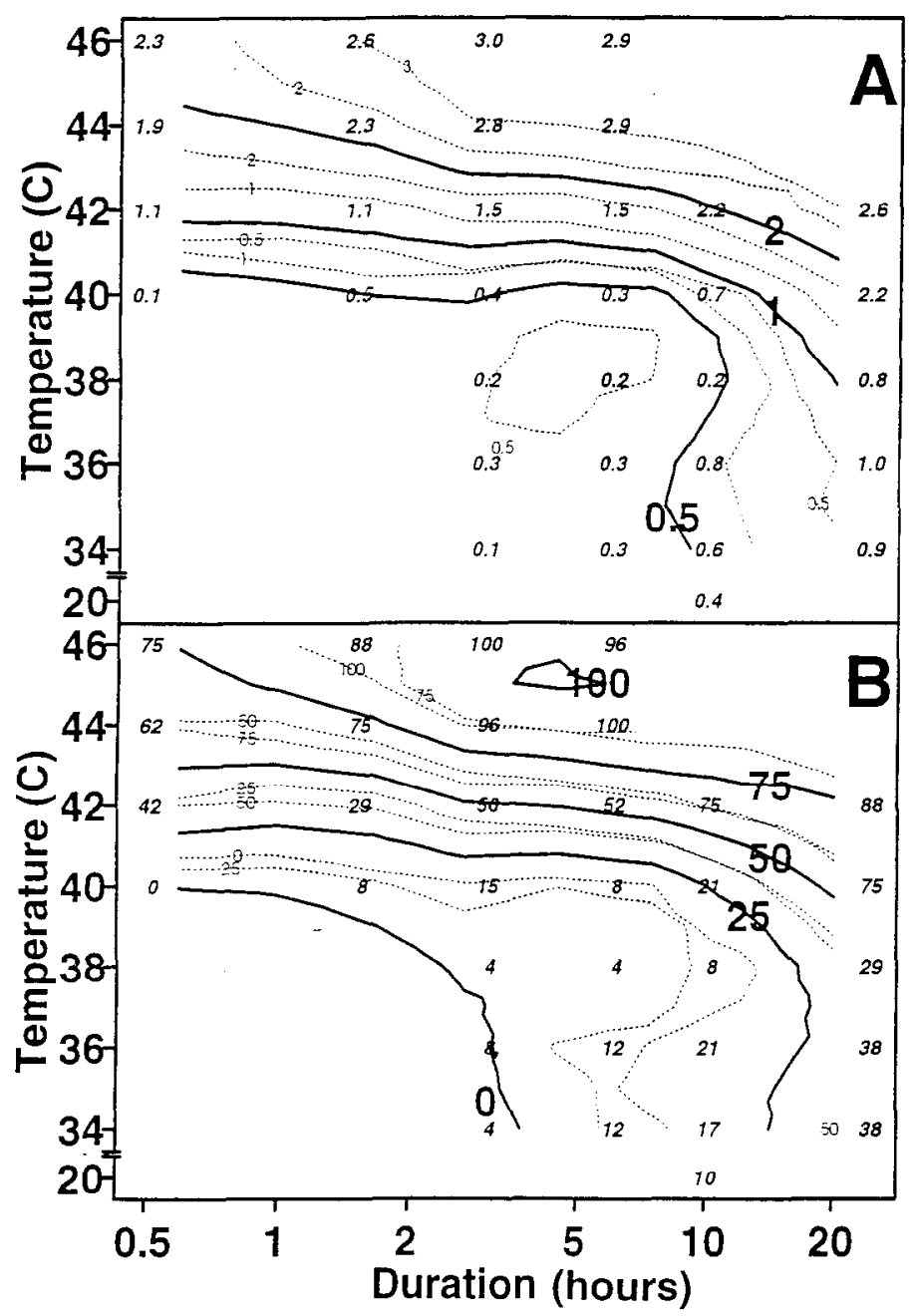

Fig. 3. Contour plot of mean severity (A) and percent incidence (B) (percentage of fruit with levels sl) of uneven ripening of avocado after heat treatment at 34 to $46 \mathrm{C}$ for 0.5 to $24 \mathrm{~h}$ followed by storage at $2 \mathrm{C}$ for 4.5 weeks. Severity of uneven ripening of unheated $(20 \mathrm{C}$ ) fruit stored at either $2 \mathrm{C}$ or $6 \mathrm{C}$ was $0.4 \pm 1.0$ and 0.1 \pm 0.2 , respectively, and incidence was $10 \% \pm 25 \%$ and $2 \% \pm 7 \%$, respectively. Uneven ripening rated on a scale of 0 to $3(0=$ none, $3=$ extreme). Bold lines (with large numbers) represent fitted contour lines, and broken lines on either side (small nonbold numbers) represent $95 \%$ confidence intervals. Small, bold italicized numbers represent the mean values for each treatment combination. were variable, but a marked inhibition of ethylene production was shown in fruit treated at 44 and $46 \mathrm{C}$ for $6 \mathrm{~h}$ (Table 1). Respiration rates were not affected by temperature or HT duration (data not shown).

In Expt. 2, the effect of a 38C HT for 3,6,10, or $24 \mathrm{~h}$ on ethylene production was investigated. Onset of the ethylene climacteric was delayed $(P<0.001)$ by the 24 -h treatment ( 3.4 days vs. 1.4 to 1.8 days for the other durations), but maximum ethylene production and respiration rate were not influenced (data not shown).

Weight loss. Fruit lost weight during HTs, and a linear increase in weight loss occurred with higher temperature and increased duration of HT. The lowest weight loss $(0.3 \%$ decrease in fresh weight) was found in fruit treated at $34 \mathrm{C}$ for $3 \mathrm{~h}$, while maximum loss $(3 \%)$ occurred in fruit at $42 \mathrm{C}$ for $24 \mathrm{~h}$. HTs did not affect weight loss during storage at $2 \mathrm{C}$, with control and heat-treated fruit losing $2.5 \%$ to $3.5 \%$ over the 4.5 weeks of storage (Expts. 2 and 3; data not shown).

Northern analysis. To examine the expression of HSP genes in response to these HTs, we probed total RNA extracted from avocado flesh with cDNAs encoding two HSP genes, one representing the plant-specific, low-molecular weight HSP17 family (pFS1968), and the other the HSP70 family (pMON9575). Levels of RNA hybridizing to pFS1968 increased significantly at 38C relative to levels at 20,34 , and $36 \mathrm{C}$, reached a maximum at $40 \mathrm{C}$, and declined at higher temperatures (Fig. 6A). No RNA homologous to pFS1968 was observed in unheated fruit. At 38C, maximum levels of RNA hybridizing to pFS 1968 were observed after 6 to $10 \mathrm{~h}$. RNA hybridizing to pMON9575 (HSP70) appeared be more constitutive in the avocado flesh than pFS1968-homologous RNA, but shared a similar pattern of increasing levels with increasing temperatures up to 40C. At 38C, levels of RNA hybridizing to pMON9575 were enhanced over the 10 -h heating period and declined by $24 \mathrm{~h}$.

When fruit were held at 2C after HTs, pFS1968-homologous RNA (HSP17) was maintained at enhanced but declining levels for up to 6 weeks (Fig. 6B). Similar results were obtained for levels of pMON9575-homologous RNA (HSP70; data not shown).

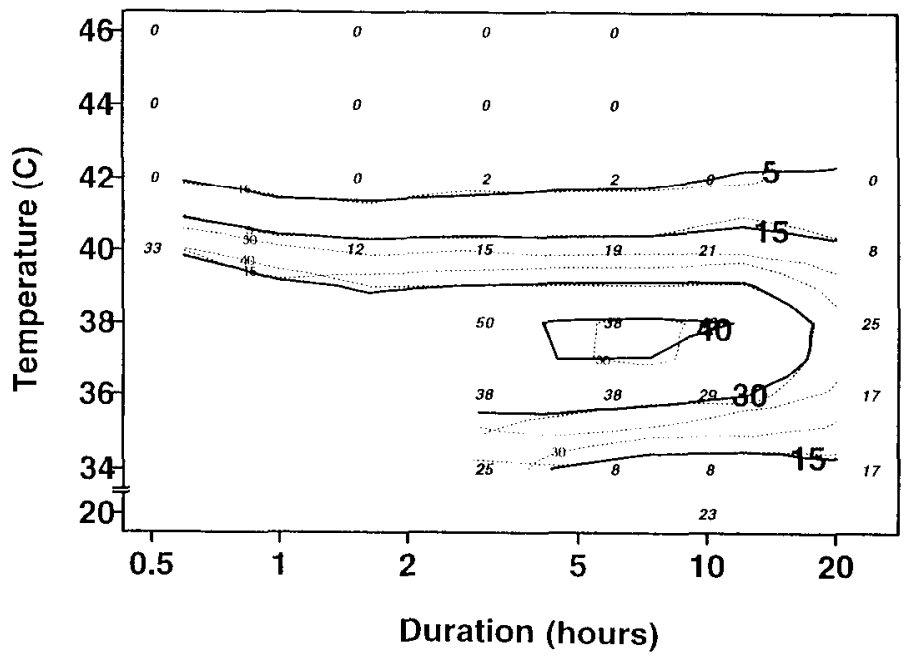

Fig. 4. Contour plot of mean percent sound avocado fruit after heat treatment at 34 to $46 \mathrm{C}$ for 0.5 to $24 \mathrm{~h}$ followed by storage at $2 \mathrm{C}$ for 4.5 weeks. Unheated (2OC) fruit stored at either $2 \mathrm{C}$ or $6 \mathrm{C}$ had $23 \% \pm 13 \%$ and $31 \% \pm 13 \%$ sound fruit, respectively. Sound fruit calculated by determining the proportion of fruit in which no disorder was greater than 1 (i.e., none, or only slight damage) within the rating scale of 0 to $3(0=$ none, $3=$ extreme). Bold lines (with large numbers) represent fitted contour lines, and broken lines on either side (small nonbold numbers) represent $95 \%$ confidence intervals. Small, bold italicized numbers represent the mean values for each treatment combination. 


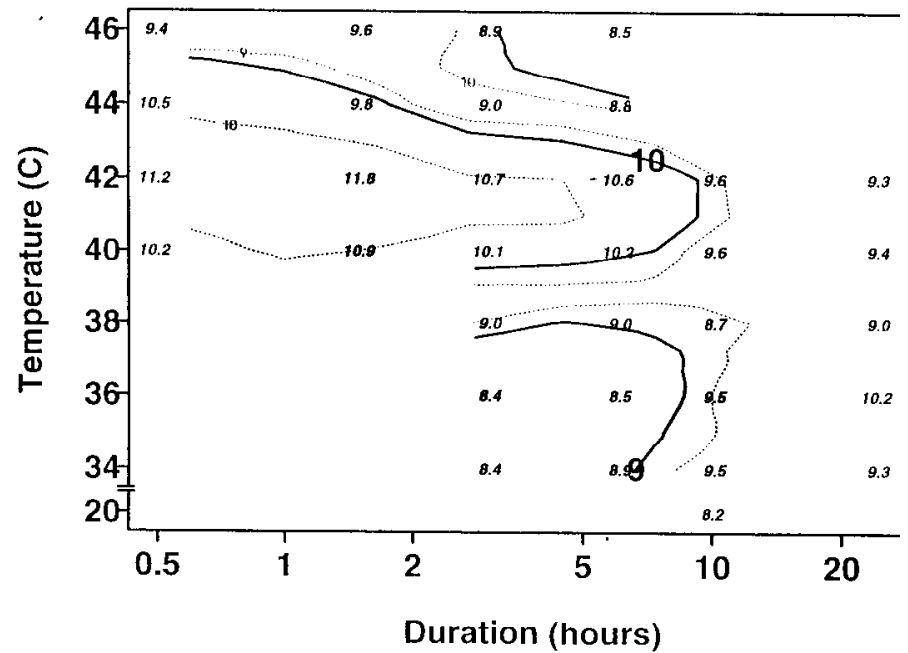

Fig. 5. Contour plot of mean shelf life of avocado after heat treatment at 34 to $46 \mathrm{C}$ for 0.5 to $24 \mathrm{~h}$ followed by storage at $2 \mathrm{C}$ for 4.5 weeks. The shelf life of unheated (20C) fruit stored at either $2 \mathrm{C}$ or $6 \mathrm{C}$ was $8.2 \pm 1.4$ and $6.3 \pm 2.6$ days, respectively. Fruit neither heat-treated nor stored had a mean shelf life of $11.2 \pm 1.4$ days. Shelf life was measured as the days to ripening at 20C. Bold lines (with large numbers) represent fitted contour lines, and broken lines on either side (small nonbold numbers) represent $95 \%$ confidence intervals. Small, bold italicized numbers represent the mean values for each treatment combination.

\section{Discussion}

Reduced chilling injury. After carrying out hot-air HTs of avocados and storing them at lower temperatures $(0$ or $2 \mathrm{C})$ than currently used by industry, we found HTs at which neither external chilling injury nor heat damage occurred. These HTs are $34 \mathrm{C}$ for $3 \mathrm{~h}, 36 \mathrm{C}$ for 3 and $6 \mathrm{~h}, 38 \mathrm{C}$ for $3,6,10$, and $24 \mathrm{~h}$, and $40 \mathrm{C}$ for 0.5 $\mathrm{h}$ to $10 \mathrm{~h}$.

In presenting our results, we did not distinguish between external damage due to chilling and that due to heat in heat-treated fruit stored at 0 or $2 \mathrm{C}$, since the damage symptoms are similar. The symptoms can be separated, however, as is demonstrated in Fig. 1, with fruit treated at 25 or $34 \mathrm{C}$ and stored at either 0 or $6 \mathrm{C}$. After storage, fruit heated at these temperatures and stored at $0 \mathrm{C}$ had external damage that we assumed was chilling injury, since this damage was not observed at $6 \mathrm{C}$. However, fruit treated at $42 \mathrm{C}$ for $6 \mathrm{~h}$ had similar external damage levels if stored at 0 or $6 \mathrm{C}$. This suggests that the external damage observed in these fruit was due to heat damage only. Damage due to heat has also been observed in 'Fuerte' fruit heated at $43 \mathrm{C}$ for $12 \mathrm{~h}$ and stored at 7C (Kerbel et al., 1987). Thus, we suggest that external injury of fruit heattreated at $34 \mathrm{C}$ and less is due to chilling injury, while injury of fruit treated at the higher temperatures (e.g., 42C) is heat damage.

Fruit quality ripening and shelf life. Apart from determining a HT that reduces external chilling injury, we also wanted to define a treatment that did not reduce internal fruit quality. We did not observe chilling injury expressed as a specific internal symptom such as fresh graying (Sanxter et al., 1994; Zauberman et al., 1985). All of the internal disorders we observed occurred in fruit held at $20 \mathrm{C}$ only and in those stored at 0,2 , or $6 \mathrm{C}$ and then ripened at $20 \mathrm{C}$. Therefore, we suggest that many of these symptoms, such as uneven ripening (Fig. 3), vascular, flesh, and seed cavity browning, are part of natural senescence and are enhanced by a prior lowtemperature treatment.

The reduced proportion of sound fruit observed after higher HTs (42C) agrees with other published results. Several authors have reported various damage symptoms, such as abnormal ripening and browning, which increase with longer duration and higher HT temperatures in 'Hass' (Florissen et al., 1994), 'Fuerte' (Kerbel et al., 1987; Sinclair and Lindgren, 1955), and 'Dickinson' (Sinclair and Lindgren, 1955) avocados. Conversely, heating 'Hass' fruit at $40 \mathrm{C}$ for 24 or $48 \mathrm{~h}$ without subsequent storage results in normal ripening (Eaks, 1978). The most likely reason for this difference in response is the lack of storage after HT, and differences due to growing conditions may also be involved.

A short shelf life will ultimately limit the marketability of a crop; thus, part of our aim was to extend shelf life after storage. This was achieved in two ways. First, storage at $2 \mathrm{C}$, a temperature below the current industry standard (6C), slowed ripening during storage, as reflected in an extended shelf life of about 2 days over

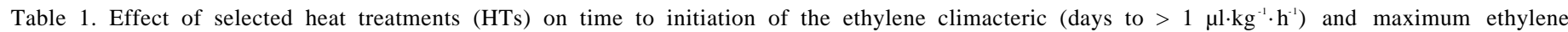
production $\left(\mu \mathrm{l} \cdot \mathrm{kg}^{-1} \cdot \mathrm{h}^{-1}\right)$ after removing avocados from storage (Expts. 2 and 3). Maximum ethylene production values are the log ${ }^{10}$-transformed data with the back-transformed value in parenthesis.

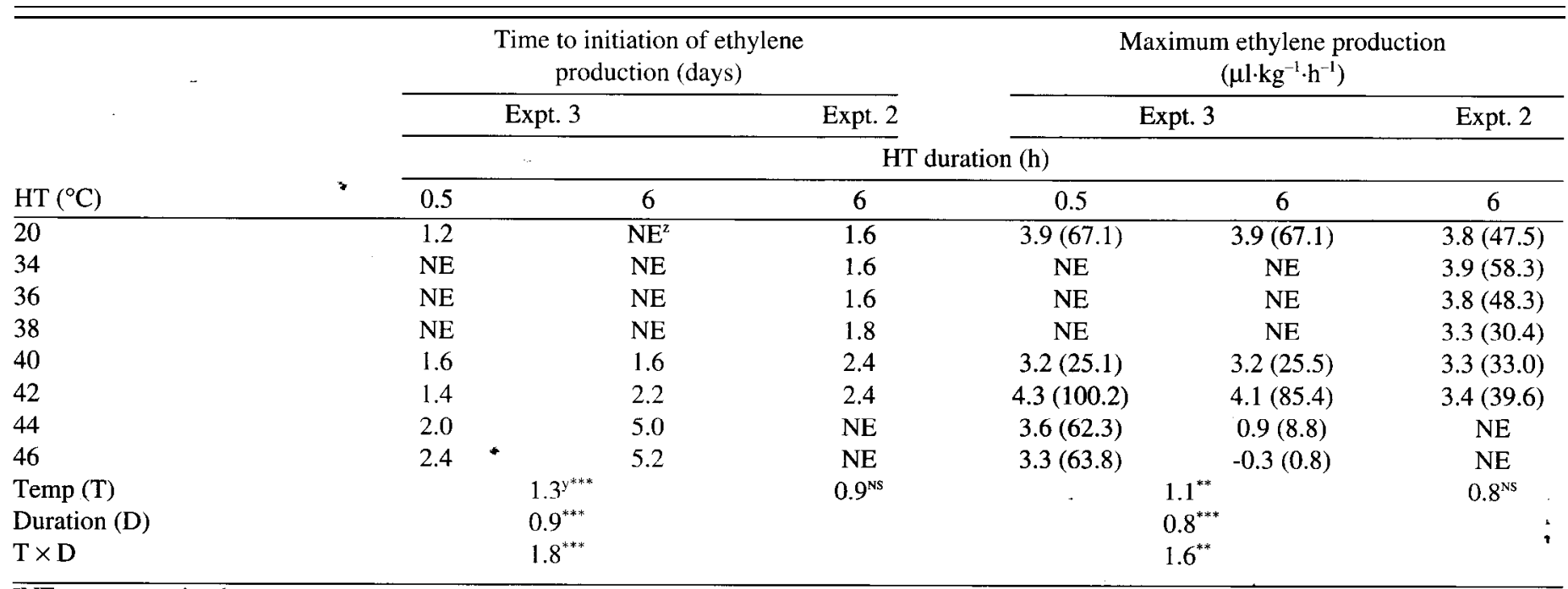

$\mathrm{NE}=$ not examined.

$y_{\text {LSD }}$ significance at $P=0.05$.

$\mathrm{Ns},{ }^{* *}, * * *$ Nonsignificant or significant at $P=0.01$ or 0.001 , respectively. 
that of the unheated fruit stored at $6 \mathrm{C}$. Second, HTs that did not damage fruit delayed ripening by a further 1 to 2 days relative to unheated fruit stored at the same temperature (2C). In some cases, this resulted in a shelf life of nearly as long as that of unheated, unstored fruit. Sanxter et al. (1994) found no effect of HT with subsequent storage on ripening rate in 'Sharwil' avocados, while Florissen et al. (1994) noted an increased rate of ripening with 'Hass' under a HT protocol similar to that used in this work. It is unclear why different researchers report different effects, but these may be a result of maturity or cultural differences.

Thus, only some of the HTs that minimized external damage after cold storage also effectively maintained overall fruit quality. Treatments found to minimize external damage, increase shelf life over that of unheated stored controls, and result in levels of sound fruit equal to or greater than that of unheated fruit stored at $6 \mathrm{C}$ (the industry standard) were $38 \mathrm{C}$ for 3,6 , or $10 \mathrm{~h}$ and $40 \mathrm{C}$ for $0.5 \mathrm{~h}$. These treatments are similar to those recommended by Sanxter et al. (1994) and Florissen et al. (1994), but the duration of treatment is shorter, especially compared with the $17 \mathrm{~h}$ of Sanxter et al. (1994). This work has defined an optimum HT for 'Hass' avocado of 38 to $40 \mathrm{C}$. However, we have found that this is not necessarily the case with all crops. For instance, chilling injury in persimmon is reduced most effectively at temperatures $>45 \mathrm{C}$ (unpublished data).

Ethylene production has been shown to be reduced by HTs in several fruit, including apples and papaya (Klein, 1989; Chan, 1986), and it has been suggested that reduced ACC oxidase gene expression by heat is correlated with the inhibition of fruit ripening (Picton and Grierson, 1988). In 'Hass' avocado, HTs at higher temperatures (e.g., 44 and 46C) reduced ethylene production. However, there was little clear evidence for an effect of HT on ethylene production or respiration rates directly reflected in the delayed ripening (increased shelf life; Fig. 5). These results are similar to those observed in 'Fuerte' avocados, where a 6-h HT at $35 \mathrm{C}$ did not reduce the peak level of ethylene production after storage, while fruit failed to reach a climacteric peak after a 12-h $\begin{array}{lllllll}20 & 34 & 36 & 38 & 40 & 42 & \mathrm{C}\end{array}$

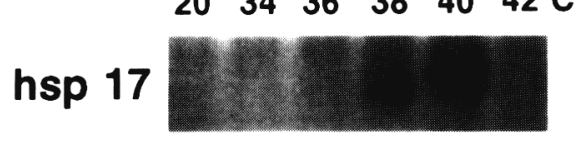

hsp 70

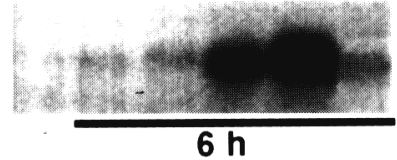

$38 \mathrm{C}$
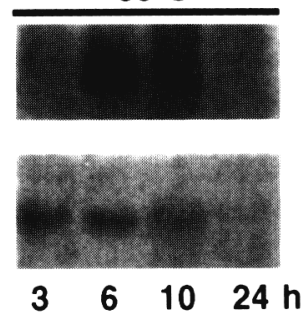

$\begin{array}{llll}3 & 6 & 10 & 24 \mathrm{~h}\end{array}$
Storage duration at $2 \mathrm{C}$ (weeks)

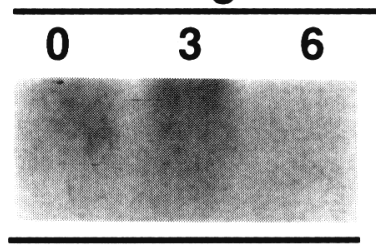

Unheated

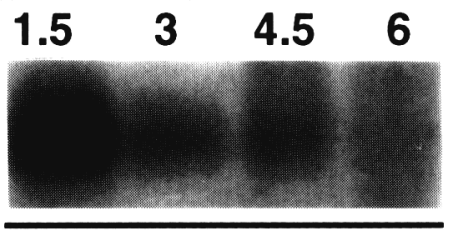

Heạted
Fig. 6 (A) Northern analysis of RNA extracted from avocado fruit flesh directly after heat treatments at the given temperatures (left column) and durations (right column) (Expt. 2). Northern blots were probed with inserts of pFS 1968 (soybean HSP17 cDNA) and pMON9575 (petunia HSP70 cDNA). (B) Northern analysis of RNA extracted from avocado fruit flesh after a heat treatment of 38C for $6 \mathrm{~h}$ and storage at $2 \mathrm{C}$ for up to 6 weeks. Northern blots were probed with the insert of pFS 1968 (soybean HSP17 cDNA).
HT at 43C (Kerbel et al., 1987). The lack of correlation of ethylene production with ripening rate may be explained by the complex interaction of HT with subsequent storage, particularly at chilling temperatures.

Northern analysis. Our data show that levels of RNA hybridizing to cDNAs encoding two HSPs from common HSP families (low molecular weight and HSP70) were increased at temperatures in the heat shock range (above 34 to 36C). It may be significant that the highest levels of HSP transcripts occurred at 38 and 40C and durations of 3 to $10 \mathrm{~h}$, the same HTs that provided the best protection against chilling injury (Fig. 6A vs. Fig. 2). We have previously found enhanced levels of HSP gene mRNA in heated tomato fruit, and these levels were maintained during subsequent low-temperature storage (Lurie et al., 1993). This phenomenon is confirmed in avocados (Fig. 6B) and raises the possibility that the gene products may have some protective role when fruit are stored at chilling temperatures immediately after a HT. We are currently examining the synthesis of HSPs in heated avocados The chaperone-like role of HSPs (Howarth and Ougham, 1993) indicates that they might protect enzymes and proteins that are otherwise damaged or cease functioning during storage. A possible role for HSPs in reducing chilling injury in cucumber cotyledons has already been proposed (Lafuente et al., 1991).

We conclude that the optimal HTs (38C for 3 to $10 \mathrm{~h}$ and $40 \mathrm{C}$ for $0.5 \mathrm{~h}$ ) reduced external damage levels of fruit subsequently stored at $2 \mathrm{C}$ to that of fruit stored at $6 \mathrm{C}$ without reducing internal quality once ripened at 20C. Benefits of these HTs include longer shelf life due to the HT and to the lower temperature at which fruit may be stored and transported. Disinfestation may also be possible in countries where avocado insect pests are susceptible to low temperatures (Kerbel et al., 1987; Sanxter et al., 1994).

\section{Literature Cited}

Bower, J.P. and J.G. Cutting. 1988. Avocado fruit development and ripening physiology. Hort. Rev. 10:229-271.

Chan, H.T. 1986. Effects of heat treatments on the ethylene forming enzyme system in papayas. J. Food Sci. 51581-583.

Cleveland, W.S., E. Grosse, and W.M. Shyu. 1992. Local regression models. In: J.M. Chambers and T.J. Hastie (eds.). Statistical models in S. Wadsworth and Brooks/Cole, Pacific Grove, Calif.

Eaks, I.L. 1978. Ripening, respiration, and ethylene production of 'Hass' avocado fruit at 20 to 40C. J. Amer. Soc. Hort. Sci. 103:576-578.

Florissen, P., B. McGlasson, J. Conroy, and P. Holford. 1994. The effect of 'heat shock' treatment on chilling injury in avocados (Persea americana Mill.). Proc. Australasian Postharvest Conf. 1993:145-147.

Lawes Agricultural Trust. 1990. Genstat reference manual. version 5.22. Lawes Agricultural Trust, Rothamsted Experimental Station, Hertfordshire, U.K. Clarendon Press, Oxford.

Hopkirk, G., A. White, D.J. Beever, and S.K. Forbes. 1994. Influence of postharvest temperatures and the rate of fruit ripening on internal postharvest rots and disorders of New Zealand 'Hass' avocado fruit. N.Z. J. Crop Hort. Sci. 22:305-311.

Howarth, C.J. and H.J. Ougham. 1993. Gene expression under temperature stress. New Phytol. 125:1-26.

Kerbel, E.L., F.G. Mitchell, and G. Mayer. 1987. Effect of postharvest heat treatments for insect control on the quality and market life of avocados. HortScience 22:92-94.

Klein, J.D. 1989. Ethylene biosynthesis in heat-treated apples, p. 184190. In: M. Clijsters, R. de Proft, R. Marcelle, and M. van Pouke (eds.). Biochemical and physiological aspects of ethylene production in lower and higher plants. Kluwer, Dordrecht, The Netherlands.

Klein, J.D. and S. Lurie. 1990. Prestorage heat treatment as a means of improving poststorage quality of apples. J. Amer. Soc. Hort. Sci. 115:265-269.

Klein, J.D. and S. Lurie. 1991. Postharvest heat treatment and fruit quality. 
Postharvest News Info. 2:15-19.

Klein, J.D., S. Lurie, and R. Ben-Arie. 1990. Quality and cell wall components of 'Anna' and 'Granny Smith' apples treated with heat, calcium, and ethylene. J. Amer. Soc. Hort. Sci. 115:954-958.

Lafuente, M.T., A. Belver, M.G. Guye, and M.E. Saltveit. 199 1. Effect of temperature conditioning on chilling injury of cucumber cotyledons. Plant Physiol. 95:443-449.

Lurie, S. and J.D. Klein. 1990. Heat treatment of ripening apples: Differential effects on physiology and biochemistry. Physiol. Plant. 78:181 186.

Lurie, S. and J.D. Klein. 1991. Acquisition of low-temperature tolerance in tomatoes by exposure to high-temperature stress. J. Amer. Soc. Hort. Sci. 116:1007-1012.

Lurie, S., J.D. Klein, C.B. Watkins, G.S. Ross, P.K. Boss, and I.B. Ferguson. 1993. Prestorage heat treatments of tomatoes prevent chilling injury and reversibly inhibit ripening. Acta Hort. 343:283-285.

MacRae, E.A. 1987. Development of chilling injury in New Zealand grown 'Fuyu' persimmon during storage. N.Z. J. Expt. Agr. 15:333344.

Maindonald, J. 1992. Statistical design, analysis and presentation issues. N.Z. J. Agr. Res. 35:121-141.

McCollum, G.T., S. D' Aquino, and R.E. McDonald. 1993. Heat treatment inhibits mango chilling injury. HortScience 28:197-198.

Paull, R.E. 1990. Postharvest heat treatments and fruit ripening. Postharvest News Info. 1:355-363.

Picton, S. and D. Grierson. 1988. Inhibition of expression of tomato- ripening genes at high temperature. Plant Cell Environ. 11:265-272.

Saltveit, M.E. 1991. Prior temperature exposure affects subsequent chilling sensitivity. Physiol. Plant. 82:529-536.

Sanxter, S.S., K.A. Nishijima, and H.T. Chan. 1994. Heat-treating 'Sharwil' avocado for cold tolerance in quarantine cold treatments. HortScience 29:1166-1 168 .

Schoffl, F., E. Raschke, and R.T. Hagao. 1984. The DNA sequence analysis of soybean heat-shock genes and identification of possible regulatory promoter elements. EMBO J. 3:2491-2497.

Sinclair, W.B. and D.L. Lindgren. 1955. Vapour heat sterilization of California citrus and avocado fruits against fruit-fly insects. J. Econ. Entomol. 48: 133-1 38.

Statistical Sciences Inc. 1991. S-PLUS user's manual. version 3.0. vol. 2. Statistical Sciences, Seattle.

Veierskov, B., L.B. Ferguson, and M. Lay-Yee. 1992. Conjugation of ubiquitin to proteins during greening of etiolated oat plants. J. Plant Physiol; 139:749-754.

Wild, B.L. and C.W. Hood. 1989. Hot dip treatments reduce chilling injury in long-term storage of 'Valencia' oranges. HortScience 24:109110.

Winter, J., R. Wright, N. Duck, C. Gasser, R. Fraley, and D. Shah. 1988. The inhibition of petunia hsp70 mRNAs processing during $\mathrm{CdCl}_{2}$ stress. Mol. Gen. Genet. 211:315-319.

Woolf, A.B., C.B. Watkins, LB. Ferguson, and M. Lay-Yee. 1994. Dry heat treatments of avocado and the reduction of chilling injury during storage. Proc. Australasian Postharvest Conf. 1993:177.

Zauberman, G., Y. Fuchs, and M. Akerman. 1985. Peroxidase activity in avocado fruit stored at chilling temperatures. Scientia Hort. 26:261-265. 